Article

\title{
Monitoring of Non- $\beta$-Lactam Antibiotic Resistance-Associated Genes in ESBL Producing Enterobacterales Isolates
}

\author{
Pottathil Shinu ${ }^{1, *}$, Rajesh Bareja ${ }^{2}$, Anroop B. Nair ${ }^{3}{ }^{(D}$, Vashishth Mishra ${ }^{2}$, Snawar Hussain ${ }^{1}(\mathbb{D}$, \\ Katharigatta N. Venugopala ${ }^{3,4}{ }^{\mathbb{C}}$, Nagaraja Sreeharsha ${ }^{3,5} \mathbb{C}^{\circ}$, Mahesh Attimarad ${ }^{3} \mathbb{1}$ and \\ Sahibzada Tasleem Rasool ${ }^{1}$ \\ 1 Department of Biomedical Sciences, College of Clinical Pharmacy, King Faisal University, \\ Al-Ahsa 31982, Saudi Arabia; shhussain@kfu.edu.sa (S.H.); srasool@kfu.edu.sa (S.T.R.) \\ 2 Department of Microbiology, Faculty of Medicine, Government Medical College and Hospital, \\ Badaun 243601, India; rajeshbareja@gmail.com (R.B.); vashishtmmishra38@gmail.com (V.M.) \\ 3 Department of Pharmaceutical Sciences, College of Clinical Pharmacy, King Faisal University, \\ Al-Ahsa 31982, Saudi Arabia; anair@kfu.edu.sa (A.B.N.); kvenugopala@kfu.edu.sa (K.N.V.); \\ sharsha@kfu.edu.sa (N.S.); mattimarad@kfu.edu.sa (M.A.) \\ 4 Department of Biotechnology and Food Technology, Durban University of Technology, \\ Durban 4001, South Africa \\ 5 Department of Pharmaceutics, Vidya Siri College of Pharmacy, Off Sarjapura Road, Bangaluru 560035, India \\ * Correspondence: spottathail@kfu.edu.sa; Tel.: +966-559-732794
}

Received: 28 October 2020; Accepted: 8 December 2020; Published: 9 December 2020

Abstract: Genetic context of extended spectrum $\beta$-Lactamase (ESBL) producing Enterobacterales and its association with plasmid mediated quinolone resistance (PMQR), aminoglycoside modifying enzymes (AME) and Trimethoprim/Sulfamethoxazole (TMP-SMX) resistance is little known from North India. Therefore, the current study was aimed to investigate the frequency of Non- $\beta$-Lactam antibiotic resistance associated genes in extended spectrum $\beta$-Lactamase producing Enterobacterales. For this study, Non-Duplicate phenotypically confirmed ESBL producing Enterobacterales isolates $(\mathrm{N}=186)$ were analyzed for ESBLs, PMQRs, AMEs and TMP-SMX resistance genes using polymerase chain reaction (PCR). PCR detected presence of PMQR genes in $81.29 \%(\mathrm{~N}=139)$ of ESBL isolates $(\mathrm{N}=171)$, AME genes in $60.82 \%$ and TMP-SMX resistance genes in $63.74 \%$ of the isolates. Molecular characterization of ESBL producing Enterobacterales showed $84.79 \%$ bla $a_{T E M}$ followed by $73.68 \%$ bla $_{C T X-M}, 43.86 \%$ bla $a_{S H V}, 19.88 \%$ bla $a_{P E R}$ and $9.94 \% b l a_{V E B}$, respectively. Analysis of PMQR genes revealed $77.7 \%$ aac $\left(6^{\prime}\right)-l b-c r$ the most commonly detected gene followed by $67.63 \%$ oq $x B, 62.59 \%$ oq $x A$, $43.17 \%$ qnrB, $19.42 \%$ qnrD, $18.7 \%$ qnrS, $9.35 \%$ qnr $A, 3.6 \%$ qep $A$ and $2.88 \%$ qnrC, respectively. Analysis of AMEs gene profile demonstrated $81.73 \%$ aac $\left(6^{\prime}\right)-I b$, the most frequently encountered gene followed by $46.15 \%$ aph (3')-Ia, $44.23 \%$ ant (3")-Ia, respectively. A $100 \%$ prevalence of sul1, followed by $\mathrm{dfr} A(54.63 \%)$ and sul $2(15.74 \%)$ was observed. In summary, prevalence of ESBL-Producing genes (particularly bla and bla $_{\text {CTX-M }}$ ) along with PMQR, AMEs, and TMP-SMX resistant genes may potentially aid in the transfer of antimicrobial resistance among these strains.

Keywords: Enterobacterales; extended spectrum $\beta$-Lactamase; plasmid mediated quinolone resistance; aminoglycoside modifying enzymes; trimethoprim/sulfamethoxazole resistance; Gram-negative bacteria

\section{Introduction}

$\beta$-Lactam antibiotics are used for treating most of the human infections that are caused by Gram-negative bacteria belonging to the family Enterobacterales [1]. However, the use of $\beta$-Lactam 
antibiotics is challenging due to the emergence of various antimicrobial resistance (AMR) mechanisms particularly the presence of extended-spectrum $\beta$-lactamases (ESBLs) [2]. ESBLs are considered the most extensively encountered AMR mechanisms prevalent in Enterobacterales and other clinically significant Gram-negative bacteria [1,2]. Genes coding for ESBLs production are often located on plasmids that also carry genes coding for resistance to fluoroquinolones, aminoglycosides, trimethoprimsulfamethoxazole (TMP-SMX) [1]. Further, a high level of fluoroquinolone resistance was reported among ESBLs producing Enterobacterales [2,3]. Chromosomal mutations and plasmid-mediated quinolone resistance (PMQR) are considered the most relevant mechanisms of fluoroquinolone resistance among Enterobacterales [4,5]. Generally, PMQR determinants produce low-level of quinolone resistance, however, reports reveal that the presence of PMQR determinants may enhance the degree of chromosomal mediated quinolone resistance if present in the same strain [3,6-8]. PMQRs are mainly categorized into three groups; (i) quinolone resistance ( $q n r)$ gene mediated (ii) quinolones modifying aminoglycoside acetyltransferase encoding genes $\left(a a c\left(6^{\prime}\right)-I b-c\right)$, (iii) plasmid-mediated quinolone efflux pumps qepA, oqxA, and $o q x B[6]$.

Literature indicates that synthesis of aminoglycoside modifying enzymes (AMEs) is an important AMR mechanism that produce high level of aminoglycoside resistance among Gram-negative bacteria [9,10]. These AMEs are grouped into three categories: (i) aminoglycoside N-acetyltransferases (AACs), (ii) aminoglycoside O-phosphotransferases (APHs), and (iii) aminoglycoside O-nucleotidyltransferases (ANTs) [10]. Further, the structural genes coding for AMEs are often located on plasmids that carry multiple resistance elements for ESBLs [11,12]. This type of association between ESBL and AMEs coding genes are of foremost apprehension in the treatment of bacterial infections. Besides resistance to $\beta$-lactams, fluoroquinolones, and aminoglycosides, members of Enterobacterales demonstrate resistance to TMP-SMX as well. However, little has been reported on the genetic context of various species of ESBL producing Enterobacterales and its association with, PMQR, AMEs TMP-SMX resistance exclusively from North India. Therefore, the current study was designed to analyze the distribution of non- $\beta$-lactam antibiotic resistance associated genes prevailing in ESBL producing Enterobacterales. To our knowledge, this is the first study that investigated the distribution of AME, PMQR and TMP-SMX resistance genes among ESBL producing Enterobacterales that are isolated from North India. Furthermore, this study included clinical isolates of different members of Enterobacterales (Escherichia coli, Klebsiella pneumonia, Citrobacter freundii, Klebsiella oxytoca, Morganella morganii Proteus mirabilis, Proteus vulgaris, and Enterobacter cloacae), while the earlier studies limited their molecular characterization in two species (E. coli and K. pneumoniae) [8,10,13]. In addition, this study explores prevalence of TMP-SMX resistance genes among ESBL producing clinical Enterobacterales, an observation that has been made only a few times earlier.

\section{Results}

Among the total phenotypically confirmed ESBL isolates $(\mathrm{N}=186)$ obtained, K. pneumoniae $16.13 \%$ (30/186), E. coli $9.67 \%$ (18/186), K. oxytoca 2.15\% (4/186), P. mirabilis $1.61 \%(3 / 186)$ and P. vulgaris $0.53 \%(1 / 186)$ were resistant to all the antibiotics tested. Table 1 shows distribution of antibiotic susceptibility pattern of various antibiotics tested against different strains of Enterobacterales. The highest antibiotic resistance rate was noted for ampicillin 95.89\% (70/73) followed by TMP-SMX 90.86\% (169/186). The resistance rate of $\beta$-lactams were: cefazolin 94.08\% (175/186), amoxicillin-clavulanic acid $77 \%$ (124/161), cefotaxime 82.8\% (154/186), cefepime 66.67\% (124/186), ceftazidime 89.78\% (164/186), ceftriaxone $88.17 \%$ (164/186), cefoxitin 76.83\% (126/164), cefpodoxime $86.11 \%(155 / 180)$, cefuroxime $86.02 \%$ (160/186), and ceftizoxime 83.3\% (155/186), respectively. The resistance rate of fluoroquinolones were 75.27\% (140/186), 69.89\% (130/186), 76.88\% (143/186), 75.27\% (140/186), and 71.51\% (133/186) for ciprofloxacin, levofloxacin, nalidixic acid, gatifloxacin, and moxifloxacin, respectively. Similarly, the resistance rate of aminoglycosides were 64\% (119/186), 61\% (114/186), 49\% (91/186), and 59\% $(109 / 186)$ for gentamycin, tobramycin, amikacin, and kanamycin, respectively. The lowest resistance 
rates were associated with imipenem 43.01\% (80/186) and meropenem 46.77\% (87/186), respectively (Table 2 and Supplementary Materials Table S1).

Table 1. Primers used for PCR and sequencing of drug resistance-associated genes from Enterobacterales.

\begin{tabular}{|c|c|c|c|c|c|}
\hline Target Gene & Primer Name & Primer Sequence $\left(5^{\prime}-3^{\prime}\right)$ & $\begin{array}{c}\text { Annealing } \\
\text { Temperature } \\
\left({ }^{\circ} \mathrm{C}\right)\end{array}$ & $\begin{array}{l}\text { Amplicon/ } \\
\text { Product } \\
\text { Size (bp) }\end{array}$ & References \\
\hline \multirow{9}{*}{ ESBL genes } & \multirow[t]{2}{*}{ TEM } & F AGATCAGTTGGGTGCACGAG & $52{ }^{\circ} \mathrm{C}$ & 750 & [14] \\
\hline & & R TGCTTAATCAGTGAGGCACC & & \multirow[b]{2}{*}{380} & \multirow[b]{2}{*}{ [14] } \\
\hline & SHV & $\begin{array}{l}\text { F GGGAAACGGAACTGAATGAG } \\
\text { R TTAGCGTTGCCAGTGCTCG }\end{array}$ & $55^{\circ} \mathrm{C}$ & & \\
\hline & \multirow[t]{2}{*}{ CTX-M1 } & F TTAGGAARTGTGCCGCTGYA & \multirow[t]{2}{*}{$60^{\circ} \mathrm{C}$} & \multirow[t]{2}{*}{688} & \multirow[t]{2}{*}{ [15] } \\
\hline & & R CGATATCGTTGGTGGTRCCAT & & & \\
\hline & \multirow[t]{2}{*}{ PER } & F GCTCCGATAATGAAAGCGT & \multirow[t]{2}{*}{$60^{\circ} \mathrm{C}$} & \multirow[t]{2}{*}{520} & \multirow[t]{2}{*}{ [15] } \\
\hline & & R TTCGGCTTGACTCGGCTGA & & & \\
\hline & \multirow[t]{2}{*}{$V E B$} & F CATTTCCCGATGCAAAGCGT & \multirow[t]{2}{*}{$60^{\circ} \mathrm{C}$} & \multirow[t]{2}{*}{648} & \multirow[t]{2}{*}{ [15] } \\
\hline & & R CGAAGTTTCTTTGGACTCTG & & & \\
\hline & \multirow[t]{2}{*}{$q n r A$} & F AGAGGATTTCTCACGCCAGG & $57^{\circ} \mathrm{C}$ & 630 & [4] \\
\hline & & R GCAGCACTATKACTCCCAAGG & & & \\
\hline & $q n r B$ & F GGMATHGAAATTCGCCACTG & $57^{\circ} \mathrm{C}$ & 264 & [5] \\
\hline & & R TTTGCYGYYCGCCAGTCGAA & & & \\
\hline & $q n r C$ & F GGGTTGTACATTTATTGAATC & $57^{\circ} \mathrm{C}$ & 447 & [16] \\
\hline & & R TCCACTTTACGAGGTTCT & & & \\
\hline & $q n r D$ & F CGAGATCAATTTACGGGGAATA & $57^{\circ} \mathrm{C}$ & 582 & [17] \\
\hline & & R AACAAGCTGAAGCGCCTG & & & \\
\hline PMQR gene & $q n r S$ & F GCAAGTTCATTGAACAGGGT & $57^{\circ} \mathrm{C}$ & 428 & [15] \\
\hline & & R TCTAAACCGTCGAGTTCGGCG & & & \\
\hline & $a a c\left(6^{\prime}\right)-I b-c r$ & $\begin{array}{c}\text { F TTGGAAGCGGGGACGGAM } \\
\text { R ACACGGCTGGACCATA }\end{array}$ & $52{ }^{\circ} \mathrm{C}$ & 260 & [18] \\
\hline & oqxA & F GACAGCGTCGCACAGAATG & $62{ }^{\circ} \mathrm{C}$ & 339 & [4] \\
\hline & & R GGAGACGAGGTTGGTATGGA & & & \\
\hline & $o q x B$ & $\begin{array}{c}\text { F CGAAGAAAGACCTCCCTACCC } \\
\text { R CGCCGCCAATGAGATACA }\end{array}$ & $62{ }^{\circ} \mathrm{C}$ & 240 & [4] \\
\hline & qер $A$ & $\begin{array}{l}\text { F GCAGGTCCAGCAGCGGGTAG } \\
\text { R CTTCCTGCCCGAGTATCGTG }\end{array}$ & $62{ }^{\circ} \mathrm{C}$ & 218 & [19] \\
\hline & $a a c\left(2^{\prime}\right)-I a$, & F AGAAGCGCTTTACGATTTATTA & $55^{\circ} \mathrm{C}$ & 406 & [20] \\
\hline & & R GACTCCGCCTTCTTCTTCAA & $55^{\circ} \mathrm{C}$ & & \\
\hline & $a a c(3)-I a$ & F GCAGTCGCCCTAAAACAAA & $55^{\circ} \mathrm{C}$ & 441 & [20] \\
\hline & & R CACTTCTTCCCGTATGCCCAACTT & & & \\
\hline & $a a c(3)-I b$ & F GCAGTCGCCCTAAAACAAA & $55^{\circ} \mathrm{C}$ & 417 & [20] \\
\hline & & R GGATCGTCACCGTAGTCTGC & & & \\
\hline & $\operatorname{aac}(3)-I I a$ & F GGCAATAACGGAGGCGCTTCAAAA & $55^{\circ} \mathrm{C}$ & 563 & [20] \\
\hline & & R TTCCAGGCATCGGCATCTCATACG & & & \\
\hline & $\operatorname{aac}\left(6^{\prime}\right)-I a$ & F ATGAATTATCAAATTGTG & $55^{\circ} \mathrm{C}$ & 558 & [20] \\
\hline & & R TTACTCTTTGATTAAACT & & & \\
\hline & $a a c\left(6^{\prime}\right)-I b$ & F CAAAGTTAGGCATCACA & $55^{\circ} \mathrm{C}$ & 540 & [20] \\
\hline & & R ACCTGTACAGGATGGAC & & & \\
\hline & $\operatorname{aac}\left(6^{\prime}\right)-I c$ & F CTACGATTACGTCAACGGCTGC & $55^{\circ} \mathrm{C}$ & 130 & [20] \\
\hline & & R TTGCTTCGCCCACTCCTGCACC & & & \\
\hline AME genes & $\operatorname{ant}\left(2^{\prime \prime}\right)-I a$ & F ACGCCGTGGGTCGATGTTTGATGT & $55^{\circ} \mathrm{C}$ & 572 & [20] \\
\hline & & R CTTTTCCGCCCCGAGTGAGGTG & & & \\
\hline & $\operatorname{ant}\left(3^{\prime \prime}\right)-I a$ & F TCGACTCAACTATCAGAGG & $55^{\circ} \mathrm{C}$ & 245 & [20] \\
\hline & & R ACAATCGTGACTTCTACAGCG & & & \\
\hline & ant (4")-IIa & F CCGGGGCGAGGCGAGTGC & $55^{\circ} \mathrm{C}$ & 423 & [20] \\
\hline & & R TACGTGGGCGGATTGATGGGAACC & & & \\
\hline & $\operatorname{aph}\left(3^{\prime}\right)-I a$ & F CGAGCATCAAATGAAACTGC & $55^{\circ} \mathrm{C}$ & 625 & [20] \\
\hline & & R GCGTTGCCAATGATGTTACAG & & & \\
\hline & $\operatorname{aph}\left(3^{\prime \prime}\right)-I a$ & F CGGCGTGGGCGGCGACTG & $55^{\circ} \mathrm{C}$ & 557 & [20] \\
\hline & & R CCGGATGGAGGACGATGTTGG & & & \\
\hline & $\operatorname{aph}\left(3^{\prime \prime}\right)-I b$ & F GTGGCTTGCCCCGAGGTCATCA & $55^{\circ} \mathrm{C}$ & 612 & [20] \\
\hline & & R CCAAGTCAGAGGGTCCAATC & & & \\
\hline & $\operatorname{arm} A$ & F ATTTTAGATTTTGGTTGTGGC & $54.5^{\circ} \mathrm{C}$ & 101 & [21] \\
\hline & & R ATCTCAGCTCTATCAATATCG & & & \\
\hline & & R TACGTGGGCGGATTGATGGGAACC & & & \\
\hline
\end{tabular}


Table 1. Cont.

\begin{tabular}{|c|c|c|c|c|c|}
\hline Target Gene & Primer Name & Primer Sequence $\left(5^{\prime}-3^{\prime}\right)$ & $\begin{array}{c}\text { Annealing } \\
\text { Temperature } \\
\left({ }^{\circ} \mathrm{C}\right)\end{array}$ & $\begin{array}{l}\text { Amplicon/ } \\
\text { Product } \\
\text { Size (bp) }\end{array}$ & References \\
\hline \multirow{6}{*}{$\begin{array}{l}\text { TMP-SMX } \\
\text { resistance } \\
\text { genes }\end{array}$} & sul1 & F CGGCGTGGGCTACCTGAACG & $55^{\circ} \mathrm{C}$ & 432 & [22] \\
\hline & & R GCCGATCGCGTGAAGTTCCG & & & \\
\hline & sul2 & F GCGCTCAAGGCAGATGGCATT & $53{ }^{\circ} \mathrm{C}$ & 293 & [22] \\
\hline & & R GCGTTTGATACCGGCACCCGT & & & \\
\hline & dfra1 & F TGGAGTTATCGGGAATGGC & $34{ }^{\circ} \mathrm{C}$ & 334 & [22] \\
\hline & & R AACATCACCTTCCGGCTCG & & & \\
\hline
\end{tabular}

Table 2. Antibiotic susceptibility pattern of the Enterobacterales isolates obtained from wound, respiratory tract and blood and body fluid specimens.

\begin{tabular}{|c|c|c|c|c|c|c|c|c|}
\hline \multirow[b]{2}{*}{ Antibiotics } & \multicolumn{8}{|c|}{ Organisms } \\
\hline & $\begin{array}{c}\text { Escherichia } \\
\text { coli, } \\
\mathrm{N}=58(\%)\end{array}$ & $\begin{array}{l}\text { Klebsiella } \\
\text { Pneumoniae, } \\
\text { N = } 74(\%)\end{array}$ & $\begin{array}{c}\text { Proteus } \\
\text { mirabilis, } \\
\mathrm{N}=15(\%)\end{array}$ & $\begin{array}{c}\text { Citrobacter } \\
\text { freundii, } \\
N=13(\%)\end{array}$ & $\begin{array}{c}\text { Klebsiella } \\
\text { oxytoca, } \\
\mathrm{N}=11(\%)\end{array}$ & $\begin{array}{c}\text { Enterobacter } \\
\text { cloacae, } \\
\mathrm{N}=9(\%)\end{array}$ & $\begin{array}{c}\text { Proteus } \\
\text { vulgaris, } \\
\mathrm{N}=3(\%)\end{array}$ & $\begin{array}{c}\text { Morganella } \\
\text { morganii, } \\
\mathrm{N}=3(\%)\end{array}$ \\
\hline Ampicillin & $55(94.83)$ & - & $15(100)$ & - & - & - & - & - \\
\hline Cefazolin & $49(84.48)$ & 69 (93.24) & $13(86.67)$ & $12(92.31)$ & $10(90.91)$ & $7(77.78)$ & $3(100)$ & $3(100)$ \\
\hline $\begin{array}{l}\text { Amoxicillin- } \\
\text { clavulanic acid }\end{array}$ & 38 (65.52) & 64 (86.49) & $12(80)$ & - & $8(72.73)$ & - & - & - \\
\hline Cefotaxime & $48(82.76)$ & $63(85.14)$ & $9(60)$ & $13(100)$ & $8(72.73)$ & $9(100)$ & $2(66.67)$ & $2(66.67)$ \\
\hline Cefepime & $46(79.31)$ & $41(55.41)$ & $10(66.67)$ & $11(84.62)$ & $9(81.82)$ & $5(55.56)$ & $1(33.33)$ & $2(66.67)$ \\
\hline Ceftazidime & $52(89.66)$ & $66(89.19)$ & $13(86.67)$ & $11(84.62)$ & $11(100)$ & $9(100)$ & $2(66.67)$ & $3(100)$ \\
\hline Ceftriaxone & $50(86.21)$ & 71 (95.95) & $8(53.33)$ & $13(100)$ & $11(100)$ & $7(77.78)$ & $1(33.33)$ & $2(66.67)$ \\
\hline Cefoxitin & 41 (70.69) & $64(86.49)$ & $11(73.33)$ & - & $7(63.64)$ & - & $2(66.67)$ & $1(33.33)$ \\
\hline Cefpodoxime & $52(89.66)$ & 66 (89.19) & $7(46.67)$ & $10(76.92)$ & $11(100)$ & $9(100)$ & - & - \\
\hline Cefuroxime & $50(86.21)$ & $69(93.24)$ & $9(60)$ & $11(84.62)$ & $10(90.91)$ & $7(77.78)$ & $2(66.67)$ & $2(66.67)$ \\
\hline Ceftizoxime & 47 (81.03) & $67(90.54)$ & $10(66.67)$ & $10(76.92)$ & $8(72.73)$ & $9(100)$ & $2(66.67)$ & $2(66.67)$ \\
\hline Imipenem & $22(37.93)$ & $30(40.54)$ & $12(80)$ & $7(53.85)$ & $6(54.55)$ & $3(33.33)$ & 0 & 0 \\
\hline Meropenem & 27 (46.55) & $32(43.24)$ & $11(73.33)$ & $7(53.85)$ & $6(54.55)$ & $3(33.33)$ & $1(33.33)$ & 0 \\
\hline Aztreonam & $54(93.1)$ & $68(91.89)$ & $12(80)$ & $10(76.92)$ & $11(100)$ & $9(100)$ & $1(33.33)$ & $2(66.67)$ \\
\hline Gentamicin & $40(68.97)$ & $46(62.16)$ & $7(46.67)$ & $5(38.46)$ & $4(36.36)$ & $8(88.89)$ & $2(66.67)$ & $2(66.67)$ \\
\hline Tobramycin & 45 (77.59) & $50(67.57)$ & $5(33.33)$ & $7(53.85)$ & $6(54.55)$ & $7(77.78)$ & - & $1(33.33)$ \\
\hline Amikacin & $32(55.17)$ & $39(52.7)$ & $3(20)$ & $3(23.08)$ & $5(45.45)$ & $6(66.67)$ & $1(33.33)$ & - \\
\hline Kanamycin & $40(68.97)$ & $36(48.65)$ & $8(53.33)$ & $6(46.15)$ & $6(54.55)$ & $9(100)$ & $2(66.67)$ & $1(33.33)$ \\
\hline Ciprofloxacin & 45 (77.59) & $65(87.84)$ & $11(73.33)$ & $8(61.54)$ & $6(54.55)$ & $4(44.44)$ & $1(33.33)$ & $2(66.67)$ \\
\hline Levofloxacin & $32(55.17)$ & $56(75.68)$ & $11(73.33)$ & $7(53.85)$ & $8(72.73)$ & $6(66.67)$ & $2(66.67)$ & $2(66.67)$ \\
\hline Nalidixic acid & $40(68.97)$ & $64(86.49)$ & $12(80)$ & $5(38.46)$ & $8(72.73)$ & $5(55.56)$ & $1(33.33)$ & $2(66.67)$ \\
\hline Gatifloxacin & $46(79.31)$ & $62(83.78)$ & $10(66.67)$ & $6(46.15)$ & $7(63.64)$ & $4(44.44)$ & $2(66.67)$ & $2(66.67)$ \\
\hline Moxifloxacin & $42(72.41)$ & $59(79.73)$ & $12(80)$ & $7(53.85)$ & $7(63.64)$ & $3(33.33)$ & $1(33.33)$ & $2(66.67)$ \\
\hline $\begin{array}{l}\text { Trimethoprim- } \\
\text { sulfamethoxazole }\end{array}$ & $57(98.28$ & $65(87.84)$ & $15(100)$ & $11(84.62)$ & $9(81.82)$ & $9(100)$ & $2(66.67)$ & $3(100)$ \\
\hline
\end{tabular}

Table 3 demonstrates distribution of PMQR, AME, and TMP-SMX resistance genes in Enterobacterales. Among the total phenotypically confirmed ESBL isolates $(\mathrm{N}=186), \mathrm{PCR}$ confirmed presence of ESBL genes $\left(\right.$ bla $_{C T X-M}, b l a_{T E M}, b l a_{S H V}$, bla $a_{P E R}$ and bla $\left.a_{V E B}\right)$ in $91.94 \%(171 / 186)$ of Enterobacterales isolates. However, genes coding for ESBL production were not detected from K. pneumoniae $2.69 \%$ (5/186), E. coli $2.69 \%$ (5/186), K. oxytoca $1.07 \%$ (2/186), P. mirabilis $1.07 \%$ (2/186), C. freundii $0.54 \%(1 / 186)$ and therefore, these isolates were not included for further analysis. ESBL genes were detected from pus $(\mathrm{N}=97)$, respiratory tract specimens $(\mathrm{N}=44)$, blood and body fluids $(\mathrm{N}=30)$, respectively (Supplementary Materials Table S2). The detected ESBL genes (91.94\%) were distributed in different members of Enterobacterales as follows; K. pneumoniae 40.35\% (69/171), E. coli 30.99\% (53/171), P. mirabilis 7.6\% (13/171), C. freundii 7.02\% (12/171), K. oxytoca 5.2\% (9/171), E. cloacae 5.2\% (9/171), P. vulgaris $1.75 \%(3 / 171)$, and M. morganii $1.75 \%(3 / 171)$, respectively. Of the $91.94 \%(\mathrm{~N}=171)$ genotypically confirmed isolates, $b l a_{T E M} 84.79 \%(145 / 171)$ was the most common ESBL gene followed by $b l a_{C T X-M}$ $73.68 \%$ (126/171), bla $a_{S H V} 43.86 \%$ (75/171), bla $a_{P E R} 19.88 \%$ (34/171) and $b l a_{V E B} 9.94 \%$ (17/171), respectively. 
Table 3. Distribution of Extended-spectrum beta-lactamases (ESBL) and non-beta-lactamase encoding genes in genotypically confirmed strains of ESBL producing Enterobacterales.

\begin{tabular}{|c|c|c|c|c|c|c|c|c|}
\hline \multirow[b]{2}{*}{$\begin{array}{c}\text { Type of } \\
\text { Resistance }\end{array}$} & \multicolumn{8}{|c|}{ Organisms } \\
\hline & $\begin{array}{c}\text { Escherichia } \\
\text { coli, } \\
\mathrm{N}=53(\%)\end{array}$ & $\begin{array}{l}\text { Klebsiella } \\
\text { pneumoniae, } \\
\mathrm{N}=69(\%)\end{array}$ & $\begin{array}{c}\text { Proteus } \\
\text { mirabilis, } \\
\mathrm{N}=13(\%)\end{array}$ & $\begin{array}{c}\text { Citrobacter } \\
\text { freundii, } \\
\mathrm{N}=12(\%)\end{array}$ & $\begin{array}{c}\text { Klebsiella } \\
\text { oxytoca, } \\
\mathrm{N}=9(\%)\end{array}$ & $\begin{array}{c}\text { Enterobacter } \\
\text { cloacae, } \\
\mathrm{N}=9(\%)\end{array}$ & $\begin{array}{c}\text { Proteus } \\
\text { vulgaris, } \\
\mathrm{N}=3(\%)\end{array}$ & $\begin{array}{c}\text { Morganella } \\
\text { morganii, } \\
\mathrm{N}=3(\%)\end{array}$ \\
\hline \multicolumn{9}{|c|}{ ESBL } \\
\hline TEM & $46(86.8)$ & $58(84.06)$ & 12 92.31) & $9(75)$ & $7(77.78)$ & 7 (77.78) & $3(100)$ & $3(100)$ \\
\hline CTX-M & 39 (73.6) & $61(88.41)$ & $8(61.54)$ & $8(66.67)$ & $6(66.67)$ & $4(44.44)$ & ND & ND \\
\hline SHV & $29(54.7)$ & $30(43.48)$ & 2 (15.39) & $4(33.33)$ & $7(77.78)$ & $3(33.33)$ & ND & ND \\
\hline PER & $8(15.1)$ & $13(18.84)$ & $3(23.08)$ & $3(25)$ & $2(22.22)$ & $3(33.33)$ & $1(33.33)$ & ND \\
\hline$V E B$ & $1(1.89)$ & $5(7.25)$ & $8(61.54)$ & ND & $1(11.11)$ & $2(22.22)$ & ND & ND \\
\hline \multicolumn{9}{|c|}{ PMQR } \\
\hline$q n r A$ & $3(5.66)$ & ND & $8(61.54)$ & ND & ND & ND & $2(66.67)$ & ND \\
\hline$q n r B$ & $12(22.6)$ & $36(52.17)$ & ND & $6(50)$ & $5(55.56)$ & ND & ND & $1(33.33)$ \\
\hline$q n r C$ & $4(7.55)$ & ND & ND & ND & ND & ND & ND & ND \\
\hline$q n r D$ & 7 (13.2) & $17(24.64)$ & ND & ND & $3(33.33)$ & ND & ND & ND \\
\hline$q n r S$ & $11(20.8)$ & $3(4.35)$ & $9(69.23)$ & ND & ND & $3(33.33)$ & ND & ND \\
\hline$A a c-i b-c r$ & $32(60.4)$ & $51(73.91)$ & $7(53.85)$ & $7(58.33)$ & $6(66.67)$ & $2(22.22)$ & $3(100)$ & ND \\
\hline$o q x A$ & $14(26.4)$ & $58(84.06)$ & $9(69.23)$ & ND & $4(44.44)$ & $2(22.22)$ & ND & ND \\
\hline$o q x B$ & $21(39.6)$ & $62(89.86)$ & $8(61.54)$ & ND & $3(33.33)$ & ND & ND & ND \\
\hline qер $A$ & $5(9.43)$ & ND & ND & ND & ND & ND & ND & ND \\
\hline \multicolumn{9}{|c|}{ AME } \\
\hline$a a c(3)-I b$ & $2(3.77)$ & $4(5.8)$ & ND & $3(25)$ & $1(11.11)$ & $1(11.11)$ & ND & ND \\
\hline$a a c(3)-I a$ & $6(11.3)$ & ND & ND & $1(8.33)$ & ND & ND & ND & ND \\
\hline aac(3)-IIa & $18(34)$ & $19(27.54)$ & $1(7.69)$ & $3(25)$ & $2(22.22)$ & $3(33.33)$ & ND & $1(33.33)$ \\
\hline$a a c\left(6^{\prime}\right)-I b$ & $28(52.8)$ & $46(66.67)$ & $3(23.08)$ & $2(16.67)$ & $4(44.44)$ & $1(11.11)$ & ND & $1(33.33)$ \\
\hline $\operatorname{ant}\left(2^{\prime \prime}\right)-I a$ & 0 & $6(8.7)$ & ND & ND & $1(11.11)$ & $2(22.22)$ & ND & ND \\
\hline $\operatorname{ant}\left(3^{\prime \prime}\right)-I a$ & $22(41.5)$ & $17(24.64)$ & $2(15.39)$ & $3(25)$ & ND & $1(11.11)$ & $1(33.33)$ & ND \\
\hline $\operatorname{ant}\left(4^{\prime \prime}\right)-I I a$ & $8(15.1)$ & $4(5.797)$ & $1(7.69)$ & ND & ND & ND & ND & ND \\
\hline $\operatorname{aph}\left(3^{\prime}\right)-I a$ & $16(30.2)$ & $30(43.48)$ & $1(7.69)$ & ND & $1(11.11)$ & ND & ND & ND \\
\hline $\operatorname{aph}\left(3^{\prime \prime}\right)-I b$ & $20(37.7)$ & $15(21.74)$ & $1(7.69)$ & ND & $2(22.22)$ & $2(22.22)$ & ND & ND \\
\hline $\operatorname{armA}$ & $5(9.43)$ & 10 (14.49) & ND & ND & ND & ND & ND & ND \\
\hline \multicolumn{9}{|c|}{ TMP-SMX } \\
\hline sul1 & $35(66)$ & $46(66.67)$ & $6(46.15)$ & $7(58.33)$ & $6(66.67)$ & $5(55.56)$ & $2(66.67)$ & $1(33.33)$ \\
\hline sul2 & $9(17)$ & $6(8.7)$ & ND & ND & $1(11.11)$ & $1(11.11)$ & ND & ND \\
\hline$d f r A 1$ & $20(37.7)$ & $28(40.58)$ & $2(15.39)$ & $4(33.33)$ & $1(11.11)$ & $2(22.22)$ & $1(33.33)$ & $1(33.33)$ \\
\hline
\end{tabular}

Among the total phenotypically confirmed ESBL isolates $(\mathrm{N}=186), 81.72 \%(152 / 186), 70.43 \%$ (131/186), and 90.32\% (168/186), were resistant to fluoroquinolones, aminoglycosides and TMP-SMX, respectively. Out of the $91.94 \%$ (171/186) of the genotypically confirmed ESBL strains, PCR could detect $81.29 \%$ (PMQR), 60.82\% (AME), 63.74\% (TMP-SMX) of genes in these strains. Of the total PMQR genes $(81.29 \%)$ detected, the distribution of genes in different members of Enterobacterales ( $\mathrm{N}=139)$ as follows; K. pneumoniae $44.6 \%$ (62/139), E. coli $31.65 \%$ (44/139), P. mirabilis 8.63\% (12/139), C. freundii 5.03\% (7/139), K. oxytoca $5.03 \%$ (7/139), E. cloacae $2.16 \%$ (3/139), P. vulgaris $2.16 \%$ (3/139), and M. morganii $0.72 \%(1 / 139)$, respectively (Table 3). PMQR genes were detected from wound (84/139), respiratory tract specimens (27/139), blood and body fluids (28/139), respectively (Supplementary Materials Table S3). Of the total genotypically confirmed PMQR and ESBL cases $(\mathrm{N}=139)$, the most frequently detected PMQR gene was aac (6')-lb-cr 77.7\% (108/139) followed by oqxB 67.63\% (94/139), oqxA 62.59\% (87/139), qnrB 43.17\% (60/139), qnrD 19.42\% (27/139), qnrS 18.71\% (26/139), qnrA 9.35\% (13/139), qepA 3.6\% (5/139), and qnrC $2.88 \%(4 / 139)$, respectively (Supplementary Materials Table S3). Among the genotypically confirmed ESBL and PMQR positive Enterobacterales isolates that carrying qnrA gene $(\mathrm{N}=13)$, majority of the isolates to had co-existence with bla $a_{T E M}(13 / 13)$ and bla ${ }_{C T X-M}(8 / 13)$ gene (Table 4). Similarly, most of the strains carrying $q n r B$ gene $(\mathrm{N}=60)$ demonstrated coexistence with bla and $b l a_{S H V}(27 / 60)$. In contrast, strains carrying Aac-ib-cr gene $(\mathrm{N}=108)$, most of the isolates showed coexistence with bla $a_{T E M}(98 / 108), b_{C T X-M}(84 / 108), b l a_{S H V}(47 / 108), b l a_{P E R}(28 / 108)$, and bla $a_{V E B}(13 / 108)$ (Supplementary Materials Table S3). This coexistence of genes was observed among those isolates that carried oq $x A$ and $\operatorname{oq} x B$ as well. Among the isolates that carrying oq $x A(\mathrm{~N}=87)$ gene, majority of the isolates were possessing $b l a_{T E M}(72 / 87), b l a_{C T X-M}(66 / 87)$ and $b l a_{S H V}(39 / 87), b l a_{P E R}(17 / 87)$ and $b l a_{V E B}$ (12/87), respectively (Table 4 and Supplementary Materials Table S3). Similarly, isolates that possess 
oqxB genes was carrying $b l a_{T E M}(80 / 94), b l a_{C T X-M}(71 / 94)$ and $b l a_{S H V}(46 / 94), b l a_{P E R}(15 / 94)$ and $b l a_{V E B}$ (11/94), respectively. It was also noted that Enterobacterales isolates that having higher minimum inhibitory concentration (MIC) values for ciprofloxacin $(\geq 16 \mu \mathrm{g} / \mathrm{mL})$, nalidixic acid $(\geq 64 \mu \mathrm{g} / \mathrm{mL})$, levofloxacin $(\geq 32 \mu \mathrm{g} / \mathrm{mL})$,gatifoxacin $(\geq 32 \mu \mathrm{g} / \mathrm{mL})$ and moxifloxacin $(\geq 32 \mu \mathrm{g} / \mathrm{mL})$ mainly harboured $A a c-i b-c r, q n r B$, oq $x A$ and $o q x B$ genes. Further, the frequency of PMQR genes were high in isolates with higher quinolone MIC than their low MIC counterparts (Supplementary Materials Table S6).

Table 4. Coexistence of ESBL with PMQR, AME and TMP-SMX genes in Enterobacterales.

\begin{tabular}{|c|c|c|c|c|c|c|c|}
\hline \multirow{2}{*}{$\begin{array}{c}\text { Name of the Gene } \\
\text { PMQR }\end{array}$} & \multirow{2}{*}{ Name of the Organism } & \multirow{2}{*}{$\begin{array}{c}\text { Total Number } \\
\text { of Isolates }\end{array}$} & \multicolumn{5}{|c|}{ ESBL Genes } \\
\hline & & & TEM & $C T X-M$ & SHV & PER & $V E B$ \\
\hline \multirow[t]{3}{*}{$q n r A$} & Escherichia coli & 9 & 4 & 3 & 4 & 1 & ND \\
\hline & Proteus mirabilis & 8 & 7 & 4 & 1 & 2 & 4 \\
\hline & Proteus vulgaris & 2 & 2 & ND & ND & 1 & ND \\
\hline \multirow[t]{5}{*}{$q n r B$} & Escherichia coli & 12 & 7 & 5 & 8 & ND & ND \\
\hline & Klebsiella pneumonia & 36 & 30 & 33 & 15 & 5 & 3 \\
\hline & Citrobacter freundii & 6 & 5 & 3 & 1 & 1 & ND \\
\hline & Klebsiella oxytoca & 5 & 4 & 2 & 3 & 1 & 1 \\
\hline & Morganella morganii & 1 & 1 & ND & ND & ND & ND \\
\hline$q n r C$ & Escherichia coli & 4 & 4 & 2 & ND & ND & ND \\
\hline \multirow[t]{3}{*}{$q n r D$} & Escherichia coli & 7 & 7 & 7 & 4 & 2 & ND \\
\hline & Klebsiella pneumonia & 17 & 15 & 13 & 12 & 7 & 2 \\
\hline & Klebsiella oxytoca & 3 & 3 & ND & 1 & ND & 1 \\
\hline \multirow[t]{4}{*}{$q n r S$} & Escherichia coli & 11 & 9 & 11 & 1 & 3 & 1 \\
\hline & Klebsiella pneumonia & 3 & 3 & ND & 2 & 1 & 1 \\
\hline & Proteus mirabilis & 9 & 9 & 4 & 2 & 2 & 6 \\
\hline & Enterobacter cloacae & 3 & 3 & 1 & ND & 1 & 1 \\
\hline \multirow[t]{7}{*}{$A a c-i b-c r$} & Escherichia coli & 32 & 30 & 29 & 9 & 8 & 1 \\
\hline & Klebsiella pneumonia & 51 & 46 & 43 & 30 & 13 & 5 \\
\hline & Proteus mirabilis & 7 & 6 & 3 & 1 & 2 & 5 \\
\hline & Citrobacter freundii & 7 & 5 & 4 & 2 & 1 & 0 \\
\hline & Klebsiella oxytoca & 6 & 5 & 4 & 5 & 2 & 1 \\
\hline & Enterobacter cloacae & 2 & 2 & 1 & ND & 1 & 1 \\
\hline & Proteus vulgaris & 3 & 3 & ND & ND & 1 & ND \\
\hline \multirow[t]{5}{*}{$o q x A$} & Escherichia coli & 14 & 10 & 9 & 6 & ND & ND \\
\hline & Klebsiella pneumonia & 58 & 49 & 50 & 30 & 13 & 5 \\
\hline & Proteus mirabilis & 9 & 8 & 5 & 1 & 2 & 5 \\
\hline & Klebsiella oxytoca & 4 & 3 & 1 & 2 & 1 & 1 \\
\hline & Enterobacter cloacae & 2 & 2 & 1 & ND & 1 & 1 \\
\hline \multirow[t]{4}{*}{$o q x B$} & Escherichia coli & 21 & 16 & 13 & 13 & ND & ND \\
\hline & Klebsiella pneumonia & 62 & 53 & 54 & 30 & 13 & 5 \\
\hline & Proteus mirabilis & 8 & 8 & 4 & 2 & 2 & 5 \\
\hline & Klebsiella oxytoca & 3 & 3 & ND & 1 & ND & 1 \\
\hline \multirow[t]{2}{*}{ qерA } & Escherichia coli & 5 & 3 & 1 & 4 & ND & ND \\
\hline & & AME & & & & & \\
\hline \multirow[t]{5}{*}{$a a c(3)-I b$} & Escherichia coli & 2 & 2 & 2 & ND & ND & ND \\
\hline & Klebsiella pneumonia & 4 & 4 & 1 & 2 & 2 & 1 \\
\hline & Citrobacter freundii & 3 & 1 & 3 & 2 & ND & ND \\
\hline & Klebsiella oxytoca & 1 & 1 & ND & ND & ND & ND \\
\hline & Enterobacter cloacae & 1 & 1 & ND & ND & 1 & ND \\
\hline \multirow[t]{2}{*}{$a a c(3)-I a$} & Escherichia coli & 6 & 6 & 6 & 4 & 3 & ND \\
\hline & Citrobacter freundii & 1 & ND & 1 & 1 & ND & ND \\
\hline \multirow[t]{7}{*}{$\operatorname{aac}(3)-I I a$} & Escherichia coli & 18 & 16 & 18 & 4 & 4 & 1 \\
\hline & Klebsiella pneumonia & 19 & 17 & 18 & 13 & 5 & ND \\
\hline & Proteus mirabilis & 1 & 1 & 1 & 1 & ND & 1 \\
\hline & Citrobacter freundii & 3 & 3 & 1 & ND & 1 & ND \\
\hline & Klebsiella oxytoca & 2 & 2 & ND & ND & ND & 1 \\
\hline & Enterobacter cloacae & 3 & 3 & 1 & ND & 1 & 1 \\
\hline & Morganella morganii & 1 & 1 & ND & ND & ND & ND \\
\hline
\end{tabular}


Table 4. Cont.

\begin{tabular}{|c|c|c|c|c|c|c|c|}
\hline \multirow{2}{*}{$\begin{array}{c}\text { Name of the Gene } \\
\text { PMQR }\end{array}$} & \multirow{2}{*}{ Name of the Organism } & \multirow{2}{*}{$\begin{array}{c}\text { Total Number } \\
\text { of Isolates }\end{array}$} & \multicolumn{5}{|c|}{ ESBL Genes } \\
\hline & & & TEM & CTX-M & SHV & PER & $V E B$ \\
\hline \multirow[t]{4}{*}{$a a c\left(6^{\prime}\right)-I b$} & Escherichia coli & 28 & 26 & 28 & 8 & 8 & 1 \\
\hline & Klebsiella pneumonia & 46 & 41 & 38 & 30 & 13 & 5 \\
\hline & Proteus mirabilis & 3 & 3 & 2 & 1 & 1 & 2 \\
\hline & Citrobacter freundii & 2 & ND & 2 & 2 & ND & ND \\
\hline \multirow[t]{3}{*}{$a a c\left(6^{\prime}\right)-I b$} & Klebsiella oxytoca & 4 & 3 & 1 & 2 & 1 & 1 \\
\hline & Enterobacter cloacae & 1 & 1 & ND & ND & ND & 1 \\
\hline & Morganella morganii & 1 & 1 & ND & ND & ND & ND \\
\hline \multirow[t]{3}{*}{$\operatorname{ant}\left(2^{\prime \prime}\right)-I a$} & Klebsiella pneumonia & 6 & 4 & 6 & 6 & 2 & ND \\
\hline & Klebsiella oxytoca & 1 & 1 & ND & ND & ND & ND \\
\hline & Enterobacter cloacae & 2 & 2 & 1 & ND & 1 & 1 \\
\hline \multirow[t]{6}{*}{$\operatorname{ant}\left(3^{\prime \prime}\right)-I a$} & Escherichia coli & 22 & 19 & 17 & 9 & 3 & ND \\
\hline & Klebsiella pneumonia & 17 & 15 & 15 & 13 & 8 & ND \\
\hline & Proteus mirabilis & 2 & 2 & 1 & 1 & 1 & 2 \\
\hline & Citrobacter freundii & 3 & 3 & 1 & ND & 1 & ND \\
\hline & Enterobacter cloacae & 1 & 1 & 1 & ND & 1 & ND \\
\hline & Proteus vulgaris & 1 & 1 & ND & ND & 1 & ND \\
\hline \multirow[t]{3}{*}{$\operatorname{ant}\left(4^{\prime \prime}\right)-I I a$} & Escherichia coli & 8 & 8 & 8 & 3 & 1 & ND \\
\hline & Klebsiella pneumonia & 4 & 4 & 4 & 2 & ND & ND \\
\hline & Proteus mirabilis & 1 & 1 & ND & ND & 1 & 1 \\
\hline \multirow[t]{4}{*}{$\operatorname{aph}\left(3^{\prime}\right)-I a$} & Escherichia coli & 16 & 16 & 16 & 8 & 5 & ND \\
\hline & Klebsiella pneumonia & 30 & 27 & 25 & 22 & 11 & 1 \\
\hline & Proteus mirabilis & 1 & 1 & ND & ND & 1 & 1 \\
\hline & Klebsiella oxytoca & 1 & 1 & ND & ND & ND & ND \\
\hline \multirow[t]{5}{*}{$\operatorname{aph}\left(3^{\prime \prime}\right)-I b$} & Escherichia coli & 20 & 17 & 15 & 9 & 3 & ND \\
\hline & Klebsiella pneumonia & 15 & 15 & 14 & 10 & 5 & ND \\
\hline & Proteus mirabilis & 1 & 1 & ND & ND & 1 & 1 \\
\hline & Klebsiella oxytoca & 2 & 2 & ND & ND & ND & 2 \\
\hline & Enterobacter cloacae & 2 & 2 & 1 & ND & 1 & 1 \\
\hline \multirow[t]{2}{*}{$\operatorname{arm} A$} & Escherichia coli & 5 & 2 & 2 & 5 & ND & ND \\
\hline & Klebsiella pneumonia & 10 & 10 & 9 & 5 & 3 & \\
\hline \multicolumn{8}{|c|}{ TMP-SMX resistance genes } \\
\hline \multirow[t]{8}{*}{ sul1 } & Escherichia coli & 35 & 31 & 29 & 10 & 8 & 1 \\
\hline & Klebsiella pneumonia & 46 & 41 & 38 & 30 & 13 & 5 \\
\hline & Proteus mirabilis & 6 & 6 & 3 & 1 & 2 & 4 \\
\hline & Citrobacter freundii & 7 & 5 & 4 & 2 & 1 & ND \\
\hline & Klebsiella oxytoca & 6 & 5 & 3 & 4 & 2 & 1 \\
\hline & Enterobacter cloacae & 5 & 4 & 3 & 2 & 2 & 2 \\
\hline & Proteus vulgaris & 2 & 2 & ND & ND & 1 & ND \\
\hline & Morganella morganii & 1 & 1 & ND & ND & ND & ND \\
\hline \multirow[t]{4}{*}{ sul2 } & Escherichia coli & 9 & 7 & 4 & 4 & ND & ND \\
\hline & Klebsiella pneumonia & 6 & 6 & 3 & 2 & 2 & 2 \\
\hline & Klebsiella oxytoca & 1 & 1 & ND & ND & ND & ND \\
\hline & Enterobacter cloacae & 1 & 1 & 1 & ND & ND & 1 \\
\hline \multirow[t]{8}{*}{$d f r A 1$} & Escherichia coli & 20 & 18 & 20 & 5 & 5 & 1 \\
\hline & Klebsiella pneumonia & 28 & 26 & 23 & 18 & 10 & 2 \\
\hline & Proteus mirabilis & 2 & 2 & 1 & 1 & 1 & 2 \\
\hline & Citrobacter freundii & 4 & 2 & 3 & 2 & ND & ND \\
\hline & Klebsiella oxytoca & 1 & 1 & ND & ND & ND & ND \\
\hline & Enterobacter cloacae & 2 & 2 & 1 & ND & 1 & 1 \\
\hline & Proteus vulgaris & 1 & 1 & ND & ND & 1 & ND \\
\hline & Morganella morganii & 1 & 1 & ND & ND & ND & ND \\
\hline
\end{tabular}

ND: Not detected.

Out of the $60.82 \%(104 / 171)$ of AME genes detected, the distribution of these genes in the Enterobacterales ( $\mathrm{N}=104)$ is as follows; K. pneumoniae $44.23 \%(46 / 104)$, E. coli $38.46 \%(40 / 104)$, P. mirabilis $2.89 \%$ (3/104), C. freundii 5.77\% (6/104), K. oxytoca 3.84\% (4/104), E. cloacae $2.89 \%(3 / 104)$, P. vulgaris $0.96 \%$ (1/104), and M. morganii 0.96\% (1/104), respectively (Table 3). The distribution of different AME genes in various specimens include wound $(\mathrm{N}=69)$, respiratory tract specimens $(\mathrm{N}=7)$, blood and body fluids $(\mathrm{N}=28)$, respectively. Of the total genotypically confirmed ESBL and AME cases $(\mathrm{N}=104)$, the most frequently encountered AME gene was aac (6')-Ib 81.73\% (85/104), followed by aph(3')-Ia 46.15\% (48/104), 
ant(3")-Ia 44.23\% (46/104), aac(3)-IIa 45.19\% (47/104), aph(3")-Ib 35.58\%, (37/104), armA 14.42\% (15/104), ant(4")-IIa 12.5\% (13/104), aac(3)-Ib 10.58\%(11/104), ant(2")-Ia 8.65\% (9/104), aac(3)-Ia 6.73\% (7/104), respectively (Table 3). However, $a a c\left(2^{\prime}\right)-I a, a a c\left(6^{\prime}\right)-I a, a a c\left(6^{\prime}\right)-I c$ and $a p h\left(3^{\prime \prime}\right)-I a$ were not detected in any of the strains analyzed (Supplementary Materials Table S4).

Of the total AME positive Enterobacterale isolates $(\mathrm{N}=104)$ that carried aac $(3)$-IIa genes $(\mathrm{N}=47)$, majority of the isolate had co-existence with bla $a_{T E M}(43 / 47)$ and bla $a_{C T X-M}(38 / 47)$ genes. Similarly, strains carrying aac $\left(6^{\prime}\right)$-Ib gene $(\mathrm{N}=85)$ demonstrated coexistence with bla $a_{T E M}(75 / 85), b l a_{C T X-M}(72 / 85)$, and bla $a_{S H V}(43 / 85)$. However, strains carrying ant (3")-Ia gene $(\mathrm{N}=46)$, majority of isolates showed co-existence with $b l a_{T E M}(41 / 46), b l a_{C T X-M}(35 / 46)$ and bla $a_{S H V}(23 / 46)$. This coexistence of genes were also observed among the isolates that carrying $a p h\left(3^{\prime \prime}\right)-I a$ and $a p h\left(3^{\prime \prime}\right)-I b$ wherein majority of the strains were equally harbouring both $b l a_{T E M}$ and $b l a_{C T X-M}$ genes (Table 4 and Supplementary Materials Table S4). Further, isolates that showed high MIC values for gentamicin $(\geq 16 \mu \mathrm{g} / \mathrm{mL})$, tobramycin $(\geq 16 \mu \mathrm{g} / \mathrm{mL})$, amikacin $(\geq 64 \mu \mathrm{g} / \mathrm{mL})$ and kanamycin $(\geq 64 \mu \mathrm{g} / \mathrm{mL})$ mainly harboured $a a c\left(6^{\prime}\right)-I b, a p h\left(3^{\prime \prime}\right)-I a$, aac(3)-IIa, ant(3")-Ia genes, respectively (Supplementary Materials Table S7). The rate of incidence of aminoglycoside resistance genes was high in isolates that having higher aminoglycoside MICs as compared to strains with low degree of aminoglycoside MICs (Supplementary Materials Table S7).

Of the $63.74 \%(108 / 171)$ of TMP-SMX resistant ESBL producing Enterobacterales isolates, the distribution of TMP-SMX resistance genes are as follows; K. pneumoniae 42.59\% (46/108), E. coli $34.26 \%$ (37/108), P. mirabilis 5.56\% (6/108), C. freundii 6.5\% (7/108), K. oxytoca 5.56\% (6/108), E. cloacae $4.63 \%$ (5/108), P. vulgaris $1.86 \%$ (2/108), and M. morganii 0.92\% (1/108), respectively (Table 3). These TMP-SMX resistance genes were distributed among wound $(\mathrm{N}=78)$, respiratory tract specimens $(\mathrm{N}=4)$, blood and body fluids $(\mathrm{N}=28)$, respectively. Of the total genotypically confirmed ESBL and TMP-SMX resistant isolates $(\mathrm{N}=108)$, the most common TMP-SMX resistance gene was sul1 100\% (108/108), followed by dfrA 54.63\% (59/108) and sul2 15.74\% (17/108), respectively (Supplementary Materials Table S5).

Of the total ESBL isolates that carrying sul1 gene $(\mathrm{N}=108)$, majority of the isolates were having co-existence with bla $a_{T E M}(95 / 108), b_{C T X-M}(81 / 108)$ and bla $a_{S H V}(51 / 108)$ genes, respectively. Similarly, strains carrying $d f r A 1$ gene $(\mathrm{N}=59)$ demonstrated coexistence with bla $a_{T E M}(53 / 59)$ and bla $a_{C T X-M}(48 / 59)$ (Supplementary Materials Table S5). Further, Enterobacterales isolates that showed elevated MICs $(4 / 76 \geq 16 / 304 \mu \mathrm{g} / \mathrm{mL})$ for TMP-SMX mainly harbored sul1 and $d f r A 1$ genes. It was also observed that the frequency of TMP-SMX genes was higher in strains with high TMP-SMX MIC values (Supplementary Materials Table S8).

Table 5 summarizes the comparison of origin of strain and type of resistance genes detected. The data analysis shows no direct correlation exists between origin of strain (wound, respiratory tract specimens, blood and body fluids) and the type of resistance genes (ESBL, PMQR, AME, and TMP-SMX resistance genes) detected. The number of types of resistance genes detected in wound specimens were significantly $(p<0.05)$ different from that found in the respiratory tract specimens (Table 5).

Table 5. Comparison of origin of strain and type of resistance genes.

\begin{tabular}{|c|c|c|c|}
\hline \multirow[b]{2}{*}{ Type of Resistance Gene } & \multicolumn{3}{|c|}{ Origin of Strain } \\
\hline & $\begin{array}{l}\text { Wound Specimens } \\
\qquad \mathrm{N}=97(\%)\end{array}$ & $\begin{array}{l}\text { Respiratory Tract Specimens } \\
\qquad \mathrm{N}=44(\%)\end{array}$ & $\begin{array}{l}\text { Blood and Body Fluids } \\
\qquad N=30(\%)\end{array}$ \\
\hline \multicolumn{4}{|l|}{ ESBL } \\
\hline TEM & 85 (87.62) & $35(79.54)$ & $25(83.33)$ \\
\hline CTX-M & $70(72.16)$ & 34 (77.27) & $22(73.33)$ \\
\hline SHV & $40(41.23)$ & $19(43.18)$ & $16(53.33)$ \\
\hline$P E R$ & $29(29.89)$ & ND & $4(13.3)$ \\
\hline$V E B$ & $14(14.43)$ & $1(2.27)$ & $2(6.6)$ \\
\hline
\end{tabular}


Table 5. Cont.

\begin{tabular}{|c|c|c|c|}
\hline & \multicolumn{3}{|c|}{ Origin of Strain } \\
\hline Type of Resistance Gene & $\begin{array}{l}\text { Wound Specimens } \\
\mathrm{N}=97(\%)\end{array}$ & $\begin{array}{l}\text { Respiratory Tract Specimens } \\
\qquad \mathrm{N}=44(\%)\end{array}$ & $\begin{array}{c}\text { Blood and Body Fluids } \\
\quad \mathrm{N}=30(\%)\end{array}$ \\
\hline \multicolumn{4}{|l|}{ PMQR } \\
\hline$q n r A$ & 13 (13.4) & ND & ND \\
\hline$q n r B$ & 19 (19.58) & $17(38.63)$ & $24(80)$ \\
\hline qnrC & ND & ND & $4(13.3)$ \\
\hline$q n r D$ & $27(27.83)$ & ND & ND \\
\hline$q n r S$ & $26(26.8)$ & ND & ND \\
\hline$a a c\left(6^{\prime}\right)-l b-c r$ & $76(78.35)$ & $8(18.18)$ & $24(80)$ \\
\hline oq $x A$ & $43(44.33)$ & $16(36.36)$ & $28(93.33)$ \\
\hline $\operatorname{oq} x B$ & $39(40.2)$ & 27 (61.36) & $28(93.33)$ \\
\hline qерA & ND & ND & $5(16.66)$ \\
\hline \multicolumn{4}{|l|}{ AMEs } \\
\hline$a a c(3)-I b$ & $11(11.34)$ & ND & ND \\
\hline$a a c(3)-I a$ & $6(6.19)$ & ND & $1(3.33)$ \\
\hline $\operatorname{aac}(3)-I I a$ & $44(45.36)$ & ND & $3(10)$ \\
\hline$a a c\left(6^{\prime}\right)-I b$ & $62(63.91)$ & $3(6.82)$ & $20(66.67)$ \\
\hline $\operatorname{ant}\left(2^{\prime \prime}\right)-I a$ & $9(9.28)$ & ND & ND \\
\hline $\operatorname{ant}\left(3^{\prime \prime}\right)-I a$ & $33(34)$ & ND & 13 (41.94) \\
\hline ant $\left(4^{\prime \prime}\right)-I I a$ & $13(13.4)$ & ND & ND \\
\hline $\operatorname{aph}\left(3^{\prime}\right)-I a$ & $39(40.21)$ & ND & $9(30)$ \\
\hline $\operatorname{aph}\left(3^{\prime \prime}\right)-I a$ & $1(1.03)$ & ND & ND \\
\hline $\operatorname{aph}\left(3^{\prime \prime}\right)-I b$ & $25(25.77)$ & ND & $15(50)$ \\
\hline $\operatorname{arm} A$ & $8(8.24)$ & $4(9.09)$ & $3(10)$ \\
\hline \multicolumn{4}{|l|}{ TMP-SMX resistance gene } \\
\hline sul 1 & $78(80.41)$ & $3(6.82)$ & $27(90)$ \\
\hline sul 2 & $8(8.24)$ & ND & $9(30)$ \\
\hline$d f r A$ & $59(60.82)$ & ND & ND \\
\hline
\end{tabular}

ND: Not detected.

\section{Discussion}

The current study investigated the frequency of non- $\beta$-lactam antibiotic resistance associated genes among ESBL producing Enterobacterales. It was observed that the prevalence of ESBL genes detected in the current study (particularly among E. coli and K. pneumoniae) were comparable with earlier studies [2,22]. The most commonly encountered ESBL gene in this study was $b l a_{T E M}(84.79 \%)$ followed by $b l a_{C T X-M}(73.68 \%), b l a_{S H V}(43.86 \%), b l a_{P E R}(18.71 \%)$ and $b l a_{S H V}(9.94 \%)$, respectively. These findings were in accordance with an earlier study wherein most prevalent ESBL gene found was $b l a_{T E M}(73 \%)$ followed by $b l a_{C T X-M}(25-100 \%)$ and $b l a_{S H V}(23 \%)$ [2]. The low prevalence of bla $a_{P E R}$ and $b l a_{V E B}$ in the present study were comparable with the data reported by Khurana et al. [2]. Further, it was observed that most of the ESBL producing organisms were resistant to fluoroquinolones, aminoglycosides and TMP-SMX, respectively. This may be possibly due to the co-existence of PMQR, AME and TMP-SMX resistance genes in the same plasmids that also code for ESBL proteins [22].

In the present study, PCRs detected presence of PMQR genes in $81.29 \%(\mathrm{~N}=139)$ of genotypically confirmed ESBL isolates $(\mathrm{N}=171)$, indicating the presence of high frequency of PMQR genes among ESBL strains. Interestingly, K. pneumoniae (44.6\%) was having higher number of PMQR genes detected followed by E. coli $(31.65 \%)$. This observation is in accordance with an earlier study wherein, PMQR genes were more frequently encountered among E. coli, Klebsiella species, and Enterobacter species [3]. However, the frequency of occurrence of PMQR genes were low among Enterobacter cloacae in this study. This is probably due to the difference in the geographical location as the earlier study was conducted in the southern part of India (where the usage of antibiotics is different). Further, the widespread antibiotic resistance prevalent in India may be attributed to readily availability of antibiotics across the pharmacy counters. This could play a major role in increased distribution of antibiotic-resistance genes throughout the population. This study included isolates that obtained from wound, respiratory tract, body fluid and blood specimens while other studies 
were performed mostly using isolates that are collected from urine $[4,9,20]$. Of the total genotypically confirmed ESBL cases $(\mathrm{N}=171)$, the most frequent PMQR gene detected was aac $\left(6^{\prime}\right)-1 b-c r(77.7 \%)$ which is in agreement with an earlier report wherein the prevalence rate was found to be $64.5 \%$ [3]. In this study, relatively higher prevalence of $q n r B(43.17 \%)$ was observed, which was in accordance with Yang et.al observation (prevalence rate $\sim 50 \%$ ) [13]. Previous studies also reported the low prevalence of $q n r D, q n r S, q n r A$, and $q n r C[4,5,22,23]$. It was observed that the distribution of efflux pumps genes among ESBL producing Enterobacterales isolates were found to be oqxB (67.63\%), oqxA (62.59\%) and qep $A(3.6 \%)$, respectively. However, this efflux pump mediated drug resistance mechanism of bacteria can be subdued using various efflux inhibitory molecules [24], for instance, the susceptibility of antibiotics against multidrug-resistant bacteria (that developed exclusively due to efflux pump mechanisms) can be enhanced in presence of efflux pump inhibitor such as omeprazole [25]. Further, the genome sequencing analysis of multidrug-resistant strains that might reveal the potential genes that are associated with multidrug efflux pumps and once the genes and gene products are identified, the molecular docking studies that may further help in developing appropriate efflux pump inhibitors. These efflux pump inhibitors can be incorporated with antibiotic molecules in order to overcome the efflux pump mediated drug resistance [26]. Further, to our knowledge, this is the first study that investigated the prevalence of PMQR among Enterobacterales in North India. However, the oq $x A$ and oq $x B$ prevalence rates were comparable with earlier reports wherein the prevalence rates were found to be $88 \%$ and $30 \%$ for $o q x A$ and $o q x B$ genes, respectively [27]. Further, the differences in the prevalence of $o q x A$ and ${ }_{q} x B$ genes may be attributed to the geographical distribution and type of isolates studied, as most of the studies were conducted on E. coli and K. pneumonia isolates [5,19]. The low prevalence of qepA observed $(3.6 \%)$ was similar with previous data $(2 \%)$ in the literature $[13,28]$. This low prevalence of qep $A$ in the current study may also indicate low incidence of qepA gene among different strains of Enterobacterales across the world [5]. In this study, the presence of PMQR genes were associated with ESBL genes, possibly due to the common carriage on the same plasmids [23]. The isolates that carrying a minimum of two $\beta$-lactamases coding genes (particularly, bla $a_{T E M}$ and bla $_{C T X-M}$ ) were more likely to carry $a a c\left(6^{\prime}\right)-I b-c r$ and $q n r B$ genes. The genes that code for both ESBL and PMQR proteins are usually located on same plasmids and consequently that may have higher chances of transfer among the members of Enterobacterales. Therefore, it is very pertinent to comprehend the drug resistance mechanisms prevalent among the members of medically important bacteria as it may be a major concern for patient safety and in determination of therapeutic strategies.

Genes encoding AMEs are prevalent in various groups of bacteria [10,29-32]. In this study, prevalence of AME genes were found to be $60.82 \%$ among ESBL producing strains of Enterobacterales. This relatively higher prevalence rate of AMEs in ESBL producing strains may be due to co-existence of genes encoding ESBLs and AMEs in Gram-negative bacteria [9]. In this study, AMEs coding genes were most frequently isolated from K. pneumoniae $(44.23 \%)$ and E. coli (38.46\%). This was in accordance with an earlier study conducted by Haidar et al., wherein a higher prevalence of AME genes were reported among K. pneumoniae [9]. In the present study, the most frequently encountered AME gene was $a a c\left(6^{\prime}\right)-I b(81.73 \%)$ which is in agreement with the earlier studies (prevalence was 73\%) [9]. The predominance and coexistence of $a a c\left(6^{\prime}\right)-I b$ with other AME genes observed may be attributed to the fact that the gene coding for $a a c\left(6^{\prime}\right)$-Ib enzyme is frequently located within class I integrons. Further, it is known that the gene cassettes that carry other genes coding for AMEs can be easily incorporated into class I integrons resulting in the development of resistance to currently used aminoglycosides [10]. The other prevalent genes were aph(3')-Ia (46.15\%), followed by ant(3")-Ia (44.23\%), aac(3)-IIa (45.19\%), and $a p h\left(3^{\prime \prime}\right)-I b(35.58 \%)$. The higher prevalence of $a p h\left(3^{\prime}\right)-I a$ and $a p h\left(3^{\prime \prime}\right)-I b$ is alarming as this type of resistance may usually produce high level of aminoglycoside resistance. The prevalence of other AME genes were found to be relatively low, which is comparable with earlier studies $[9,23]$.

The TMP-SMX resistance genes such as sul1, sul2, or $d f r A$ genes are likely to be present either on chromosome or on plasmids [33,34]. In the present study, TMP-SMX resistance genes were obtained from $63.74 \%$ of ESBL producing isolates. This comparatively low detection rate of these resistance genes 
may be attributed to the presence of alternative resistance mechanisms prevailing in TMP-SMX resistant isolates [33]. However, additional investigations are required to explore the genetic basis of TMP-SMX resistance mechanisms that prevailing in various strains of Enterobacterales. Further, among the genotypically confirmed TMP-SMX resistant strains $(\mathrm{N}=108), 42.59 \%$ of $\mathrm{K}$. pneumonia isolates were carrying TMP-SMX resistance genes, followed by E. coli $(34.26 \%)$. However, due to the paucity of literatures, the comparison with earlier studies could not performed. To our knowledge, this new study report, the prevalence of TMP-SMX resistance genes among various clinical strains of ESBL producing Enterobacterales. A higher prevalence of sul1 (100\%) followed by dfrA (54.63\%) and sul2 (15.74\%), genes were noted in this study. This higher prevalence of sul1 gene may be attributed to the fact that the sul1 genes are usually located within class I integrons and this particular characteristic (which is a horizontally transferable genetic element) might have further helped in its wide distribution [35]. The comparatively higher prevalence of $d f r A 1$ (33.91\%) gene in the present study was in agreement with an earlier study wherein in the prevalence rate was also found to be high [22]. Enterobacterales isolates that showed elevated MICs for TMP-SMX mainly harbored sul1 and $d f r A 1$ genes indicating the likelihood of these genes in imparting resistance to TMP-SMX. However, no genes were detected from number of isolates that were having higher MIC values, suggesting the existence of alternative pathways of resistance in TMP-SMX resistant isolates.

\section{Materials and Methods}

\subsection{Study Setting and Clinical Specimens}

Between July 2018 and June 2019, a total of 2134 clinical samples (wound, respiratory tract specimens, blood and body fluids) received in the Microbiology laboratory, Government Medical College and Hospital, Badaun, India were analyzed for ESBL producing strains of Enterobacterales. This hospital laboratory receives samples from two civil hospitals and three primary health care centers that are attached to it. Among the total samples analyzed $(\mathrm{N}=2134)$, a total of 186 non-repetitive phenotypically confirmed ESBL producing Enterobacterales isolates (one organism per patient was included to avoid duplication) were obtained. All the isolates were identified by manual API ${ }^{\circledR}$ system (BioMérieux, Durham, NC, USA) and the results interpreted as recommended by the manufacturer. The strains included were K. pneumoniae $(\mathrm{N}=74)$, E. coli $(\mathrm{N}=58)$, . mirabilis $(\mathrm{N}=15), C$. freundii $(\mathrm{N}=13)$, K. oxytoca $(\mathrm{N}=11)$, E. cloacae $(\mathrm{N}=9)$, P. vulgaris $(\mathrm{N}=3)$ and M. morganii $(\mathrm{N}=3)$. All the clinical isolates were identified by standard laboratory procedure [11]. All the bacterial isolates were stored at $-80^{\circ} \mathrm{C}$ in glycerol for future use.

\subsection{Antimicrobial Susceptibility Testing and MIC Determination}

The antibiotic susceptibility testing was conducted by modified Kirby Bauer disc diffusion method as recommended by the Clinical Laboratory Standards Institute (CLSI) [10]. The antibiotic discs (HiMedia, Mumbai, India) tested include; ampicillin (10 $\mu \mathrm{g})$, cefazolin (30 $\mu \mathrm{g})$, amoxicillin -clavulanic acid $(20 \mu \mathrm{g}+10 \mu \mathrm{g})$, cefotaxime $(30 \mu \mathrm{g})$, cefepime $(30 \mu \mathrm{g})$, ceftazidime $(30 \mu \mathrm{g})$, ceftriaxone $(30 \mu \mathrm{g})$, cefoxitin $(10 \mu \mathrm{g})$, cefpodoxime $(30 \mu \mathrm{g})$, cefuroxime $(30 \mu \mathrm{g})$, ceftizoxime $(30 \mu \mathrm{g})$, imipenem $(10 \mu \mathrm{g})$, meropenem $(10 \mu \mathrm{g})$, aztreonam $(30 \mu \mathrm{g})$, gentamicin $(10 \mu \mathrm{g})$, tobramycin $(10 \mu \mathrm{g})$, amikacin $(30 \mu \mathrm{g})$, kanamycin $(30 \mu \mathrm{g})$, ciprofloxacin $(5 \mu \mathrm{g})$, levofloxacin $(5 \mu \mathrm{g})$, gatifloxacin $(5 \mu \mathrm{g})$, nalidixic acid $(30 \mu \mathrm{g})$, moxifloxacin $(5 \mu \mathrm{g})$, and TMP-SMX $(1.25 / 23.75 \mu \mathrm{g})$. However, some of the antibiotics were not tested against the following organisms since these organism's possess intrinsic resistance, more specifically, (a) K. pneumoniae, C. freundii, K. oxytoca, E. cloacae, P. vulgaris, and M. morganii against Ampicillin (b) C. freundii, E. cloacae, and M. morganii against amoxicillin- clavulanic acid (c) C. freundii, and E. cloacae against cefoxitin (d) P. vulgaris, and M. morganii against cefpodoxime, respectively [36]. Quality control strains used for antimicrobial susceptibility testing include E. coli (ATCC 25922) and Pseudomonas aeruginosa (ATCC 27853). 
The MIC of fluoroquinolones (MIC determined for selected antibiotics that include; ciprofloxacin, levofloxacin, nalidixic acid, gatifloxacin, and moxifloxacin), aminoglycosides (MIC calculated for; gentamycin, tobramycin, amikacin and kanamycin) and TMP-SMX were determined by broth micro dilution method and the results were interpreted in accordance with the CLSI guidelines [36]. The MICs were calculated to determine the association between presence of antibiotic resistance genes and concentration of antibiotic tested.

\subsection{Phenotypic Detection of ESBL}

ESBL activity was initially screened using disk diffusion method as recommended by CLSI [36]. Isolates that showed decreased zone of inhibition to one or more of the following antibiotic: $\leq 25 \mathrm{~mm}$ with ceftriaxone $(30 \mu \mathrm{g}), \leq 27 \mathrm{~mm}$ with cefotaxime $(30 \mu \mathrm{g}), \leq 22 \mathrm{~mm}$ with ceftazidime ( $30 \mu \mathrm{g}), \leq 17 \mathrm{~mm}$ with cefpodoxime $(10 \mu \mathrm{g})$, and $\leq 27 \mathrm{~mm}$ with aztreonam $(30 \mu \mathrm{g})$ were considered as ESBL producers (for E. coli, K. pneumoniae, and Koxytoca). However, zone size with $\leq 22 \mathrm{~mm}$ cefpodoxime $(10 \mu \mathrm{g}), \leq 22 \mathrm{~mm}$ with ceftazidime $(30 \mu \mathrm{g}), \leq 27 \mathrm{~mm}$ with cefotaxime, indicated ESBL production for P. mirabilis [36].

The double-disk synergy diffusion test (phenotypic confirmatory test for ESBL) was carried out as per CLSI recommendations. Briefly, ceftazidime (30 $\mu \mathrm{g})$ and cefotaxime $(30 \mu \mathrm{g})$ alone and in combination with clavulanic acid ( $10 \mu \mathrm{g}$; Himedia, Mumbai, India) were used. The ESBL production is confirmed when there is an increase of zone diameter $(\geq 5 \mathrm{~mm})$ around disk with antibiotic-clavulanic acid combination [36].

The disc approximation test was used to confirm the ESBL production in E. cloacae, C. freundii, P. vulgaris, and M. morganii strains. This test was performed as disc diffusion assay on Mueller-Hinton agar (MHA). Briefly, antibiotic discs containing aztreonam (30 $\mu \mathrm{g})$, ceftazidime (30 $\mu \mathrm{g})$, ceftriaxone $(30 \mu \mathrm{g})$, and cefotaxime $(30 \mu \mathrm{g})$ were kept $30 \mathrm{~mm}$ apart (center to center) around amoxicillin-clavulanic acid $(20 \mu \mathrm{g}+10 \mu \mathrm{g})$ disc on MHA plate inoculated with the organism to be tested. The MHA plates were incubated at $37^{\circ} \mathrm{C}$ for $24 \mathrm{~h}$. An increased zone of inhibition of any of the test antibiotic towards amoxicillin-clavulanic acid was considered as ESBL production [37]. The control strains used were E. coli ATCC 25922 (non-beta-lactamases producer) and K. pneumoniae ATCC 700603 (ESBL producer), respectively.

\subsection{PCR Analysis and Sequencing}

\subsubsection{Extraction of Bacterial DNA}

Bacterial DNA was obtained from the phenotypically confirmed ESBL strains of Enterobacterales using QIAamp DNA Mini Kit (Qiagen, Hilden, Germany). The DNA samples obtained by this procedure were segregated into two aliquots; first aliquot was used as template for the subsequent PCR reactions and the second aliquot was stored at $-80^{\circ} \mathrm{C}$ (Jindal Ultra Freezer (SMI-165E), Ghaziabad, India) for future use.

\subsubsection{Molecular Detection of ESBL, PMQR, AME and TMP-SMX Resistance Genes}

All the phenotypically confirmed ESBL producing Enterobacterales isolates were subjected to molecular characterization of the relevant encoding genes such as $b l a_{S H V}, b l a_{C T X-M}, b l a_{T E M}, b l a_{P E R}$, and $b_{\text {VEB }}$ by PCR using primers and PCR conditions shown in Table $1[14,15]$.

ESBL producing Enterobacterales isolates that resistant to fluoroquinolones were subjected to PCRs for detection of (i) qnr proteins coding genes such as $q n r A, q n r B, q n r C, q n r D$, and $q n r S$ (ii) quinolones modifying aminoglycoside acetyltransferase coding genes $\left(a c c\left(6^{\prime}\right)-I b-c r\right)$ and (iii) plasmid-mediated quinolone efflux pump protein encoding genes (qep $A$, oq $x A$ and oq $x B$ ) using primers and PCR conditions depicted in Table 1 [4,5,16-19].

ESBL producing aminoglycosides resistant strains of Enterobacterales were screened for AMEs coding genes $a a c\left(2^{\prime}\right)-I a, a a c(3)-I a, a a c(3)-I b$, $a a c(3)-I I a, a a c\left(6^{\prime}\right)-I a, a a c\left(6^{\prime}\right)-I b, a a c\left(6^{\prime}\right)-I c$, ant (2")-Ia, ant(3")-Ia, $\operatorname{ant}\left(4^{\prime \prime}\right)-I I a, \operatorname{aph}\left(3^{\prime}\right)-I a, \operatorname{aph}\left(3^{\prime \prime}\right)-I a, \operatorname{aph}\left(3^{\prime \prime}\right)-I b$, armA using primers described in Table 1 [20,21]. 
All isolates phenotypically resistant to TMP-SMX were subjected to PCR for detection of sul1, sul2 and $d f r A$ genes using primers and PCR conditions shown in Table 1 [22,38]. Briefly, $2 \mu \mathrm{L}(\sim 500 \mathrm{ng})$ of purified DNA was subjected to each multiplex PCR in a $100 \mu \mathrm{L}$ reaction mixture containing $1 \times$ PCR buffer (10 Tris- $\mathrm{HCl} \mathrm{pH} 8.8,\left(\mathrm{NH}_{4}\right)_{2} \mathrm{SO}_{4}, 3 \mathrm{mM} \mathrm{MgCl} 2,0.2 \%$ Tween 20), $200 \mathrm{mM}$ of each dNTPs, $0.5 \mu \mathrm{M}$ of each primer, and 2.0 units of AURA Taq DNA polymerase. Amplification was carried out as follows: initial denaturation at $95^{\circ} \mathrm{C}$ for $5 \mathrm{~min} ; 30$ cycles of denaturation at $95^{\circ} \mathrm{C}$ for $30 \mathrm{~s}$, annealing at 50-62 ${ }^{\circ} \mathrm{C}$ for $30 \mathrm{~s}$, extension/elongation at $72{ }^{\circ} \mathrm{C}$ for $45 \mathrm{~s}$; and a final elongation step at $72{ }^{\circ} \mathrm{C}$ for $5 \mathrm{~min}$. PCR-generated products were detected by electrophoresis of $7 \mu \mathrm{L}$ of each amplification mixture in $2 \%$ agarose gels in $1 \%$ Tris Borate-EDTA buffer and $0.5 \mu \mathrm{g} / \mathrm{mL}$ ethidium bromide.

To identify the ESBL, PMQR, AME, and TMP-SMX resistance genes detected in the PCR assays, automated DNA sequencing of the amplicons were conducted. More specifically, multiplex PCR-generated products were separated in $2 \%$ low melting agarose gel with $1 \%$ Tris-acetate-EDTA buffer. The PCR products were excised from the agarose gel and purified using the QIAquick PCR purification kit (Qiagen, Hilden, Germany) as recommended by the manufacturer. The nucleotide sequencing of amplicons was conducted using an ABI 3730xl DNA Analyzer (Applied Biosystems, Branch burg, NJ, USA). Basic Local Alignment Search Tool (BLAST) program was used to compare each ESBL, PMQR, AME, and TMP-SMX resistance gene sequences against those available in gene bank at the National Center of Biotechnology Information database.

\subsection{Statistical Analysis}

Chi-squared test was used to compare the association between the origin of strain and type of resistance genes detected. The null hypothesis will be accepted if the presence of genes in all the groups (wound, respiratory tract specimens, and blood body fluids) were similar. Dunn's multiple comparisons test was performed to compare the differences in the number of resistance genes obtained between two categories of samples. All statistical analyses were performed using Graph pad Prism (version 6, Graph-Pad Software, Inc., La Jolla, CA, USA). The statistical difference values showing $p<0.05$ were considered as significant.

\section{Conclusions}

In summary, this is the first study that investigated the occurrence of genetic determinants prevailing in ESBL producing Enterobacterales and the association of these genetic determinants with PMQR, AME, and TMP-SMX resistance genes in the north India. The current study demonstrated widespread occurrence of PMQR, AME, and TMP-SMX drug resistant genetic determinants in the ESBL producing Enterobacterales strains. Screening of PMQR genetic elements in ESBL producing Enterobacterales strains revealed high prevalence of both $a a c\left(6^{\prime}\right)-I b-c r$ and $q n r B$. However, molecular analysis of AMEs producing Enterobacterales strains showed high prevalence of $a a c\left(6^{\prime}\right)$ - $I b$ followed by aph (3')-Ia. On examination of TMP-SMX resistant strains, sul1 was found to be the most frequently encountered gene followed by $d f r A$. The association of ESBL-producing genes with the PMQR, AMEs, and TMP-SMX resistance genes may potentially aid in transfer of drug resistance determinants among these strains. Therefore, a complete understanding of PMQRs, AMEs, and other drug resistance mechanisms will help in determining rationale of treatment and infection control measures in hospital settings.

Supplementary Materials: The following are available online at http://www.mdpi.com/2079-6382/9/12/884/s1, Table S1: Antibiotic resistance pattern of Enterobacterales isolates tested, Table S2: Distribution of Enterobacterales isolates in various specimens studied, Table S3: Distribution of plasmid mediated quinolone resistance (PMQR) genes in extended spectrum beta-lactamase producing Enterobacterales isolates, Table S4: Distribution of aminoglycoside modifying enzyme (AME) genes in extended spectrum beta-lactamase producing Enterobacterales, Table S5: Distribution of TMP-SMX resistant genes in extended spectrum beta-lactamase producing Enterobacterales, Table S6: Distribution plasmid mediated quinolone resistance genes in extended spectrum beta-lactamase producing Enterobacterales isolates and its comparison with minimum inhibitory concentrations of fluoroquinolones tested, Table S7: Distribution of aminoglycoside modifying genes in extended spectrum beta-lactamase producing Enterobacterales isolates and its comparison with minimum inhibitory concentrations of aminoglycosides tested, 
Table S8: Distribution of trimethoprim-sulfamethoxazole (TMP-SMX) resistance genes in extended spectrum beta-lactamase producing Enterobacterales isolates and its comparison with minimum inhibitory concentrations of TMP-SMX tested.

Author Contributions: Conceptualization, P.S., R.B., A.B.N., V.M. and S.H.; Data Curation, P.S., R.B., A.B.N., K.N.V., N.S. and M.A.; Formal Analysis, P.S., R.B., A.B.N., N.S., M.A. and S.T.R.; Funding Acquisition, P.S., A.B.N. and S.H.; Investigation, P.S., R.B., A.B.N., V.M., S.H., K.N.V., N.S., M.A. and S.T.R.; Methodology, P.S., R.B., A.B.N., V.M., S.H., K.N.V., N.S., M.A. and S.T.R.; Writing-Original Draft Preparation, S.H., K.N.V., N.S., M.A. and S.T.R.; Writing-Review \& Editing, P.S., R.B., A.B.N. and V.M.; All authors have read and agreed to the published version of the manuscript.

Funding: The authors acknowledge the Deanship of Scientific Research at King Faisal University for the financial support under Nasher Track (Grant No.186297).

Conflicts of Interest: The authors declare no conflict of interest.

\section{References}

1. Alvarez, M.; Tran, J.H.; Chow, N.; Jacoby, G.A. Epidemiology of conjugative plasmid-mediated AmpC beta-lactamases in the United States. Antimicrob. Agents Chemother. 2004, 48, 533-537. [CrossRef] [PubMed]

2. Khurana, S.; Mathur, P.; Kapil, A.; Valsan, C.; Behera, B. Molecular epidemiology of beta-lactamase producing nosocomial Gram-negative pathogens from North and South Indian hospitals. J. Med. Microbiol. 2017, 66, 999-1004. [CrossRef] [PubMed]

3. Yugendran, T.; Harish, B.N. High incidence of plasmid-mediated quinolone resistance genes among ciprofloxacin-resistant clinical isolates of Enterobacteriaceae at a tertiary care hospital in Puducherry, India. PeerJ 2016, 4, e1995. [CrossRef] [PubMed]

4. Chen, X.; Zhang, W.; Pan, W.; Yin, J.; Pan, Z.; Gao, S.; Jiao, X. Prevalence of qnr, aac(6')-Ib-cr, qepA, and oqxAB in Escherichia coli isolates from humans, animals, and the environment. Antimicrob. Agents Chemother. 2012, 56, 3423-3427. [CrossRef] [PubMed]

5. Cattoir, V.; Poirel, L.; Rotimi, V.; Soussy, C.J.; Nordmann, P. Multiplex PCR for detection of plasmid-mediated quinolone resistance qnr genes in ESBL-producing enterobacterial isolates. J. Antimicrob. Chemother. 2007, 60, 394-397. [CrossRef] [PubMed]

6. Jacoby, G.A.; Strahilevitz, J.; Hooper, D.C. Plasmid-mediated quinolone resistance. Microbiol. Spectr. $2014,2$. [CrossRef]

7. Zhang, H.; Chang, M.; Zhang, X.; Cai, P.; Dai, Y.; Song, T.; Wu, Z.; Xu, H.; Qiao, M. Functional Identification and Evolutionary Analysis of Two Novel Plasmids Mediating Quinolone Resistance in Proteus vulgaris. Microorganisms 2020, 8. [CrossRef]

8. Teramae, M.; Osawa, K.; Shigemura, K.; Kitagawa, K.; Shirakawa, T.; Fujisawa, M.; Miyara, T. Prevalence of Quinolone Resistance of Extended-Spectrum $\beta$-Lactamase-Producing Escherichia coli with ST131-fimH30 in a City Hospital in Hyogo, Japan. Int. J. Mol. Sci. 2019, 20. [CrossRef]

9. Haidar, G.; Alkroud, A.; Cheng, S.; Churilla, T.M.; Churilla, B.M.; Shields, R.K.; Doi, Y.; Clancy, C.J.; Nguyen, M.H. Association between the Presence of Aminoglycoside-Modifying Enzymes and In Vitro Activity of Gentamicin, Tobramycin, Amikacin, and Plazomicin against Klebsiella pneumoniae Carbapenemase- and Extended-Spectrum- $\beta$-Lactamase-Producing Enterobacter Species. Antimicrob. Agents Chemother. 2016, 60, 5208-5214. [CrossRef]

10. Fernández-Martínez, M.; Ruiz Del Castillo, B.; Lecea-Cuello, M.J.; Rodríguez-Baño, J.; Pascual, Á.; Martínez-Martínez, L. Prevalence of Aminoglycoside-Modifying Enzymes in Escherichia coli and Klebsiella pneumoniae Producing Extended Spectrum $\beta$-Lactamases Collected in Two Multicenter Studies in Spain. Microb. Drug Resist. 2018, 24, 367-376. [CrossRef]

11. Winn, W.; Allen, S.; Janda, W.; Koneman, E.; Procop, G. Introduction to microbiology part II: Guidelines for the Collection, Transport, Processing, Analysis and Reporting of Cultures from Specific Specimen Sources. In Koneman's Color Atlas and Textbook of Diagnostic Microbiology, 6th ed.; Lippincott William \& Wilkins: Philadelpia, PA, USA, 2006; pp. 67-105.

12. Plattner, M.; Gysin, M.; Haldimann, K.; Becker, K.; Hobbie, S.N. Epidemiologic, Phenotypic, and Structural Characterization of Aminoglycoside-Resistance Gene aac(3)-IV. Int. J. Mol. Sci. 2020, 21. [CrossRef] [PubMed] 
13. Yang, H.Y.; Nam, Y.S.; Lee, H.J. Prevalence of plasmid-mediated quinolone resistance genes among ciprofloxacin-nonsusceptible Escherichia coli and Klebsiella pneumoniae isolated from blood cultures in Korea. Can. J. Infect. Dis. Med. Microbiol. 2014, 25, 163-169. [CrossRef] [PubMed]

14. Moland, E.S.; Hanson, N.D.; Black, J.A.; Hossain, A.; Song, W.; Thomson, K.S. Prevalence of newer beta-lactamases in gram-negative clinical isolates collected in the United States from 2001 to 2002. J. Clin. Microbiol. 2006, 44, 3318-3324. [CrossRef]

15. Dallenne, C.; Da Costa, A.; Decré, D.; Favier, C.; Arlet, G. Development of a set of multiplex PCR assays for the detection of genes encoding important beta-lactamases in Enterobacteriaceae. J. Antimicrob. Chemother. 2010, 65, 490-495. [CrossRef] [PubMed]

16. Wang, M.; Guo, Q.; Xu, X.; Wang, X.; Ye, X.; Wu, S.; Hooper, D.C.; Wang, M. New plasmid-mediated quinolone resistance gene, $\mathrm{qnrC}$, found in a clinical isolate of Proteus mirabilis. Antimicrob. Agents Chemother. 2009, 53, 1892-1897. [CrossRef]

17. Majlesi, A.; Kakhki, R.K.; Mozaffari Nejad, A.S.; Mashouf, R.Y.; Roointan, A.; Abazari, M.; Alikhani, M.Y. Detection of plasmid-mediated quinolone resistance in clinical isolates of Enterobacteriaceae strains in Hamadan, West of Iran. Saudi J. Biol. Sci. 2018, 25, 426-430. [CrossRef] [PubMed]

18. Wareham, D.W.; Umoren, I.; Khanna, P.; Gordon, N.C. Allele-specific polymerase chain reaction (PCR) for rapid detection of the aac(6')-Ib-cr quinolone resistance gene. Int. J. Antimicrob. Agents 2010, 36, 476-477. [CrossRef]

19. Yamane, K.; Wachino, J.; Suzuki, S.; Arakawa, Y. Plasmid-mediated qepA gene among Escherichia coli clinical isolates from Japan. Antimicrob. Agents Chemother. 2008, 52, 1564-1566. [CrossRef]

20. Miró, E.; Grünbaum, F.; Gómez, L.; Rivera, A.; Mirelis, B.; Coll, P.; Navarro, F. Characterization of aminoglycoside-modifying enzymes in enterobacteriaceae clinical strains and characterization of the plasmids implicated in their diffusion. Microb. Drug Resist. 2013, 19, 94-99. [CrossRef]

21. Berçot, B.; Poirel, L.; Nordmann, P. Updated multiplex polymerase chain reaction for detection of $16 \mathrm{~S}$ rRNA methylases: High prevalence among NDM-1 producers. Diagn. Microbiol. Infect. Dis. 2011, 71, 442-445. [CrossRef]

22. Arabi, H.; Pakzad, I.; Nasrollahi, A.; Hosainzadegan, H.; Azizi Jalilian, F.; Taherikalani, M.; Samadi, N.; Monadi Sefidan, A. Sulfonamide Resistance Genes (sul) M in Extended Spectrum Beta Lactamase (ESBL) and Non-ESBL Producing Escherichia coli Isolated From Iranian Hospitals. Jundishapur J. Microbiol. 2015, 8, e19961. [CrossRef] [PubMed]

23. Azargun, R.; Sadeghi, M.R.; Soroush Barhaghi, M.H.; Samadi Kafil, H.; Yeganeh, F.; Ahangar Oskouee, M.; Ghotaslou, R. The prevalence of plasmid-mediated quinolone resistance and ESBL-production in Enterobacteriaceae isolated from urinary tract infections. Infect. Drug Resist. 2018, 11, 1007-1014. [CrossRef] [PubMed]

24. Usai, D.; Donadu, M.; Bua, A.; Molicotti, P.; Zanetti, S.; Piras, S.; Corona, P.; Ibba, R.; Carta, A. Enhancement of antimicrobial activity of pump inhibitors associating drugs. J. Infect. Dev. Ctries. 2019, 13, 162-164. [CrossRef] [PubMed]

25. Chowdhury, N.; Suhani, S.; Purkaystha, A.; Begum, M.K.; Raihan, T.; Alam, M.J.; Islam, K.; Azad, A.K. Identification of AcrAB-TolC Efflux Pump Genes and Detection of Mutation in Efflux Repressor AcrR from Omeprazole Responsive Multidrug-Resistant Escherichia coli Isolates Causing Urinary Tract Infections. Microbiol. Insights 2019, 12, 1178636119889629. [CrossRef]

26. Yewale, P.P.; Lokhande, K.B.; Sridhar, A.; Vaishnav, M.; Khan, F.A.; Mandal, A.; Swamy, K.V.; Jass, J.; Nawani, N. Molecular profiling of multidrug-resistant river water isolates: Insights into resistance mechanism and potential inhibitors. Environ. Sci. Pollut. Res. Int. 2020, 27, 27279-27292. [CrossRef]

27. El-Badawy, M.F.; Tawakol, W.M.; El-Far, S.W.; Maghrabi, I.A.; Al-Ghamdi, S.A.; Mansy, M.S.; Ashour, M.S.; Shohayeb, M.M. Molecular Identification of Aminoglycoside-Modifying Enzymes and Plasmid-Mediated Quinolone Resistance Genes among Klebsiella pneumoniae Clinical Isolates Recovered from Egyptian Patients. Int. J. Microbiol. 2017, 2017, 8050432. [CrossRef]

28. Doma, A.O.; Popescu, R.; Mitulețu, M.; Muntean, D.; Dégi, J.; Boldea, M.V.; Radulov, I.; Dumitrescu, E.; Muselin, F.; Puvača, N.; et al. Comparative Evaluation of qnrA, qnrB, and qnrS Genes in Enterobacteriaceae Ciprofloxacin-Resistant Cases, in Swine Units and a Hospital from Western Romania. Antibiotics (Basel) 2020, 9. [CrossRef] 
29. Hammadi, A.; Aga, Q.; Nimer, N.; Shinu, P.; Nair, A. Antimicrobial resistance and presence of Class 1 integrons in Pseudomonas aeruginosa isolates from burn and wound infections. J. Pharm. Negat. Results 2020, 11, 36.

30. Kumar, N.; Singh, V.A.; Pottathil, S. Metallo- $\beta$-lactamase- and serine carbapenemase-producing Klebsiella spp.: A global challenge. J. Glob. Antimicrob. Resist. 2018, 12, 185-186. [CrossRef]

31. Shinu, P.; Singh, V.; Nair, A. Isoniazid and rifampin drug susceptibility testing: Application of 2,3,5-triphenyl tetrazolium chloride assay and microscopic-observation drug-susceptibility assay directly on Ziehl-Neelsen smear positive sputum specimens. Braz. J. Infect. Dis. 2016, 20, 33-40. [CrossRef]

32. Venugopala, K.N.; Tratrat, C.; Chandrashekharappa, S.; Attimarad, M.; Sreeharsha, N.; Nair, A.B.; Pottathil, S.; Venugopala, R.; Al-Attraqchi, O.H.A.; Morsy, M.A. Anti-tubercular potency and computationally-assessed drug-likeness and toxicology of diversely substituted indolizines. Indian J. Pharma. Educ. Res. 2019, 53, 545-552. [CrossRef]

33. Hu, L.F.; Chang, X.; Ye, Y.; Wang, Z.X.; Shao, Y.B.; Shi, W.; Li, X.; Li, J.B. Stenotrophomonas maltophilia resistance to trimethoprim/sulfamethoxazole mediated by acquisition of sul and dfrA genes in a plasmid-mediated class 1 integron. Int. J. Antimicrob. Agents 2011, 37, 230-234. [CrossRef] [PubMed]

34. Kanda, N.; Hashimoto, H.; Sonoo, T.; Naraba, H.; Takahashi, Y.; Nakamura, K.; Hatakeyama, S. Gram-negative Organisms from Patients with Community-Acquired Urinary Tract Infections and Associated Risk Factors for Antimicrobial Resistance: A Single-Center Retrospective Observational Study in Japan. Antibiotics (Basel) 2020, 9. [CrossRef]

35. Blahna, M.T.; Zalewski, C.A.; Reuer, J.; Kahlmeter, G.; Foxman, B.; Marrs, C.F. The role of horizontal gene transfer in the spread of trimethoprim-sulfamethoxazole resistance among uropathogenic Escherichia coli in Europe and Canada. J. Antimicrob. Chemother. 2006, 57, 666-672. [CrossRef] [PubMed]

36. Wayne, P. Performance standards for antimicrobial susceptibility testing: 20th informational supplement. In CLSI Document M100-S20; Clinical and Laboratory Standards Institute: Wayne, PA, USA, 2010.

37. Thomson, K.S.; Sanders, C.C. Detection of extended-spectrum beta-lactamases in members of the family Enterobacteriaceae: Comparison of the double-disk and three-dimensional tests. Antimicrob. Agents Chemother. 1992, 36, 1877-1882. [CrossRef]

38. Montiel-Riquelme, F.; Calatrava-Hernández, E.; Gutiérrez-Soto, M.; Expósito-Ruiz, M.; Navarro-Marí, J.M.; Gutiérrez-Fernández, J. Clinical Relevance of Antibiotic Susceptibility Profiles for Screening Gram-negative Microorganisms Resistant to Beta-Lactam Antibiotics. Microorganisms 2020, 8. [CrossRef]

Publisher's Note: MDPI stays neutral with regard to jurisdictional claims in published maps and institutional affiliations.

(C) 2020 by the authors. Licensee MDPI, Basel, Switzerland. This article is an open access article distributed under the terms and conditions of the Creative Commons Attribution (CC BY) license (http://creativecommons.org/licenses/by/4.0/). 